\title{
Evolving enzyme technology: impact on commercial poultry nutrition
}

\author{
A. J. Cowieson ${ }^{1 *}$, M. Hruby ${ }^{1}$ and E. E. M. Pierson ${ }^{2}$ \\ ${ }^{1}$ Danisco Animal Nutrition, PO Box 777, Marlborough, Wiltshire SN8 1XN, UK \\ ${ }^{2} 411$ East Gano, St Louis, Missouri 63147, USA
}

\begin{abstract}
The use of exogenous enzymes to improve the nutritional value of poultry diets is a relatively new concept. The technology is rapidly evolving, with new enzymes, enzyme combinations, and novel applications being developed as rapidly as regulatory restrictions will allow. Most researchers in the field of poultry nutrition would consider phytase to be the last significant leap forward in terms of enzyme use in the animal feed industry. However, there is a great deal of ongoing research into the next generation of enzymes with a focus on ingredient quality, predictability of response via least-square models, improvements in food safety, effect of bird age, effect of various side activities and enzyme dose, maximisation of net income and reduction in environmental pollution. It is the purpose of the present review article to summarise the current research in the area of feed enzymes for poultry and to speculate on future applications of enzymes and new enzyme technologies that may be of value to the industry in the coming years.
\end{abstract}

Poultry: Enzymes: Nutrition: Digestibility: Microflora: Modelling

\section{Introduction}

Endo- $\beta$-1-4-xylanases and $\beta$-1-3, 1-4-glucanases have been used commercially in diets that are based on wheat and barley for approximately 20 years, with a return on investment such that in many of these 'viscous grain' markets, penetration is in excess of $90 \%$ for broilers (Bedford, 2000a). Furthermore, the mode of action of these enzymes has been intensively studied and as a result is now fairly well elucidated (Bedford, 2000a). Although the use of enzymes to improve the nutritional value of wheat and barley is common practice, the use of enzymes in diets that are based on maize is not as widespread. This is likely to be due to the perception in the feed industry that maize is of a high and consistent nutritional value and so may not benefit from the addition of enzymes to the same extent as for diets that are based on viscous grains. It is undoubtedly true that the typical improvement in feed conversion ratio (FCR) that may be expected to be achieved via the use of currently available enzymes for wheat- or barley-based diets (especially for carbohydrases) is higher, or at least more consistent, than may be anticipated via the use of enzymes for diets based on maize. It is for this situation that leastsquare models can be invaluable as they are able, to a greater or lesser degree, to predict the likely response of a particular feed ingredient or diet to the addition of an exogenous enzyme (Rosen, 2001). It is likely that, in the future, the acceptance by the feed industry of novel enzymes will be driven to a great degree by the ability of the feed additive company to demonstrate efficacy over a range of doses in a consistent and predictable manner, precluding the arbitrary addition of enzymes to diets. Thus, the development of new enzyme systems or new applications of existing enzymes should be conducted alongside research into feed ingredient quality. It is the purpose of the present review article to summarise the most recent research in the area of feed enzymes and to suggest future developments that may have value for the industry in the coming years.

\section{Current research}

\section{Enzymes for wheat and barley}

There are two main modes of action that have been proposed for xylanase and $\beta$-glucanase in wheat- or barley-based diets. These include the viscosity theory and the so-called 'cage' effect (Bedford, 2002). The viscosity theory suggests that, as the incremental performance enhancement associated with the addition of these enzymes to poultry diets is beyond that which can be explained by the nutritive value of the released sugars, there must be an additional advantage conferred by the enzymes to the digestibility of the other nutrients in the diet. As high-molecular-weight soluble arabinoxylans and mixed-linked $\beta$-glucans have a high affinity for water, they have the ability to stimulate a geometric increase in the viscosity of the contents within the 
gastrointestinal (GI) tract (Bedford \& Classen, 1992; Nilsson et al. 2000). High intestinal viscosity is negatively correlated with animal performance, nutrient digestibility and is also associated with detrimental changes in the microbial flora within the distal GI tract. Thus, facilitating a reduction in viscosity with exogenous enzymes confers a nutritional advantage to the animal (Bedford \& Classen, 1992; van der Klis et al. 1993; Adeola \& Bedford, 2005; Cowieson et al. 2005; Meng et al. 2005; Sieo et al. 2005). The negative effects of viscosity on animal performance are so pronounced that the viscosity of feed ingredients (such as wheat and barley) has been suggested as being a reliable indicator of the nutritional value of the ingredient and the efficacy of exogenous pentosanases (Bedford et al. 1991; Bedford \& Classen, 1993). Furthermore, the effects of diet viscosity are more pronounced in young animals than in older birds, presumably associated with the maturity of the GI tract in older animals and the capacity to cope with soluble polysaccharides (Yasar \& Forbes, 1999, 2000). The 'cage' effect theory is associated with the effects of carbohydrases on cell walls, reducing their integrity and thus releasing nutrients that were previously encapsulated (Bedford, 2002). It is likely that both mechanisms are involved in the responses to xylanase and $\beta$-glucanase in poultry diets, leading to beneficial changes in performance, nutrient retention, a reduction in incidences of sticky droppings and wet litter and desirable changes in the microbial flora in the distal GI tract (Bedford, 2000b; Graham et al. 2003; Choct et al. 2004; Shakouri \& Kermanshahi, 2005) on their use. Currently, research in the area of carbohydrases for diets based on wheat and barley is focused on more detailed mode-of-action studies, the effects of enzymes for species other than broilers, assessing the importance of enzyme inhibitors and resistant starches and also processing effects such as particle size, conditioning temperature and feeding of whole grain.

One interesting new area of research for xylanase in wheat-based diets is the role that the molecular architecture of the enzyme plays in its affinity for soluble and insoluble fibre and the susceptibility to inhibition. For instance, a recent study by Fontes et al. (2004) demonstrated that a xylanase with a carbohydrate-binding module was approximately 5 and $6 \%$ more efficacious in a wheat- and rye-based diet, respectively, compared with a commercial enzyme preparation that did not have the ability to attach to its substrate. The authors concluded that the ability of enzymes to bind to their substrate using attachment modules increases the efficacy of the enzyme in vivo, especially associated with the hydrolysis of insoluble carbohydrate. This is highly significant as it is likely that this mode of action will allow a greater degree of hydrolysis of cell-wall material, releasing encapsulated nutrients and may have even greater significance in diets that contain a high concentration of insoluble carbohydrate (for example, for grower-finisher pig rations).

The susceptibility of exogenous enzymes to inhibition is also the subject of some discussion as the relevance of the concentration of xylanase inhibitors in wheat is not clear. However, some recent work by Ponte et al. (2004) concluded that the concentration of xylanase inhibitors in wheat was responsible for limiting the efficacy of exogenously added xylanase. Ingelbrecht et al. (2000) also noted that the efficacy of exogenous xylanase was compromised by the presence of xylanase inhibitors related to rheological properties of doughs and that differences in the efficacy of different xylanases may be ascribed to differences in the degree of inhibition between xylanases. Furthermore, there is considerable variation in the concentration of xylanase inhibitors in wheat, which arises from genetic sources as well as environmental conditions during growth, and also harvesting and storage conditions (Gebruers et al. 2002; Bonnin et al. 2005), which may contribute to variation in wheat apparent metabolisable energy and the range of responses that can be expected by using exogenous enzymes. However, some researchers have concluded that most xylanase inhibitors use a competitive exclusion mechanism and so may become saturated with substrate (exogenous xylanase) quickly (McLauchlan et al. 1999; Gebruers et al. 2004), probably leaving enough active xylanase to achieve the desired physiological effects. This may not be the case, however; according to Bonnin et al. (2005) the concentration of xylanase inhibitor in wheat is about $30 \mathrm{mg} / \mathrm{g}$, giving, on a mole:mole basis, approximately 250 times more inhibitor than added xylanase. Thus, the reason we do not see complete inactivation of exogenous xylanase commercially may be more related to the lack of contact between the two compounds caused primarily by the low moisture content of feed, than saturation of inhibitor by exogenous enzyme. Whether or not xylanase inhibitors have adverse effects on the efficacy of exogenous xylanase in vivo is not totally clear, especially in instances where the feed is conditioned at high temperatures (as xylanase inhibitors are proteinaceous), although there is evidence to suggest that these proteins are thermostable to a degree (Gebruers et al. 2004). Regardless of the true effects of xylanase inhibitors in praxis there is a significant cost associated with the presence of these compounds in cereals for suppliers of feed enzymes, as variation in the recovery of enzyme activity in feed has a negative effect on customer perception of product quality and consistency. The above studies suggest that substrate affinity and the degree of inhibition should be factors that are considered in the development of the next generation of fibre-degrading enzymes for diets for single-stomached animals.

There have been a number of recent papers published to assess the efficacy of NSP-degrading enzymes for other 'non-broiler' poultry species, probably stimulated to a degree by the requirements of the European Union legislative bodies for registration of enzyme products. Table 1 summarises some of the recent trials. Adeloa \& Bedford (2005) recently demonstrated that the nutritional value of wheat-based diets for ducks could be improved by supplementation of the diet with exogenous xylanase. In this study, weight gain and FCR were improved by approximately $12 \%$ by the addition of xylanase to a diet that was based on highly viscous wheat, but xylanase failed to elicit a response in a low-viscous wheat, suggesting that diet viscosity plays a significant role in the nutritional value of wheat for ducks. However, results contrary to these have been found in diets based on wheat, rye and triticale (Timmler \& Rodehutscord, 2001), where no apparent effect of xylanase was noted on performance parameters despite 
Table 1. Effect of supplementation of poultry diets with xylanase and/or $\beta$-glucanase on the performance of broilers, ducks, turkeys and laying hens

\begin{tabular}{|c|c|c|c|c|}
\hline Diet & Enzyme & Species & Improvement over control & Reference \\
\hline Wheat & Xylanase & Ducks & FCR, about $9 \%$; BWG, about $12 \%$ & Adeola \& Bedford (2005) \\
\hline Wheat-rye & Xylanase & Broilers & FCR, about $6 \%$; BWG, about $4 \%$ & Cowieson et al. (2005) \\
\hline Wheat-barley & Xylanase; glucanase & Turkeys & FCR, about $2 \%$ & Mathlouthi et al. (2003a) \\
\hline Wheat-barley & Xylanase; glucanase & Layers & FCR, about $4 \%$ & Mathlouthi et al. (2003b) \\
\hline Maize & Xylanase; glucanase & Layers & FCR, about $3 \%$ & Mathlouthi et al. (2003b) \\
\hline Wheat & Xylanase; glucanase & Layers & FCR, about $2 \%$ (dose dependent) & Lazaro et al. (2003) \\
\hline Rye & Xylanase; glucanase & Layers & FCR, about $6 \%$ (dose dependent) & Lazaro et al. (2003) \\
\hline Barley & Xylanase; glucanase & Layers & FCR about $4 \%$ (dose dependent) & Lazaro et al. (2003) \\
\hline Wheat & Xylanase & Broilers & FCR, about $6 \%$; BWG, about $10 \%$ & Scott $(2005)$ \\
\hline Wheat & Xylanase; glucanase & Broilers & FCR, about $5 \%$; BWG about $5 \%$ & Wang et al. (2005) \\
\hline Wheat & Xylanase & Broilers & AME, about $10 \%$ & Shakouri \& Kermanshahi (2005) \\
\hline Triticale & Xylanase & Broilers & AME, about $3 \%$ & Shakouri \& Kermanshahi (2005) \\
\hline \multicolumn{3}{|c|}{ Mean response to enzyme addition } & About $6 \%$ & \\
\hline
\end{tabular}

FCR, feed conversion ratio; BWG, body-weight gain; AME, apparent metabolisable energy.

a reduction in intestinal viscosity associated with enzyme addition. Mathlouthi et al. (2003a) recently demonstrated that similar performance enhancements could be expected with the supplementation of wheat- and barley-based diets for growing turkeys. These authors found that FCR was improved by between 2.5 and $5 \%$ depending on the concentration of wheat and barley used in the diets and that enzyme addition significantly reduced diet viscosity. It is also important to note that most of the published beneficial effects of enzymes in the diets of turkeys are gained using young $(<10$ weeks old $)$ animals and the effects of carbohydrases in older turkeys can be more difficult to demonstrate statistically. Laying hens also benefit from exogenous enzymes as demonstrated by Lazaro et al. (2003), where significant improvements in egg numbers $(2.1 \%)$ and food efficiency $(2.5 \%)$ were noted with enzyme supplementation of wheat-, barley- and rye-based diets. These authors concluded that it was the reduction in viscosity associated with the supplementation of the diets with xylanase and glucanase that was responsible for the enhanced performance. These data are supported by work by Mathlouthi et al. (2003b) who found that the performance of laying hens was improved and diet viscosity reduced by the addition of xylanase and glucanase to wheatand barley-based diets. These authors also found that the relative improvements associated with enzyme addition were proportionately greater for these viscous cereal-based diets than for maize-based diets. The use of xylanase and glucanase in wheat-, barley-, rye- and triticale-based diets for poultry is clearly effective in improving various performance parameters. However, it can be concluded that these effects are not necessarily consistent and are likely to depend on the quality of the feed ingredients being offered (i.e. the inherent apparent metabolisable energy of the cereal or, more correctly, the inherent FCR of the cereal), bird age, the nature of the microbial community in the gut, the environment in which the animals are kept or physical processing of the diets.

A recent study (Cowieson et al. 2005) demonstrated the effect that high temperature conditioning can have on wheat-based diets for broiler chickens. In this study, performance enhancements associated with xylanase addition were more pronounced in diets that had been conditioned at $90^{\circ} \mathrm{C}$ compared with those that had been conditioned at $80^{\circ} \mathrm{C}$. Chemical characterisation of the diets revealed that thermal processing had increased both viscosity and the concentration of soluble arabinoxylan in the diets (Figs. 1 and 2). Furthermore, the addition of

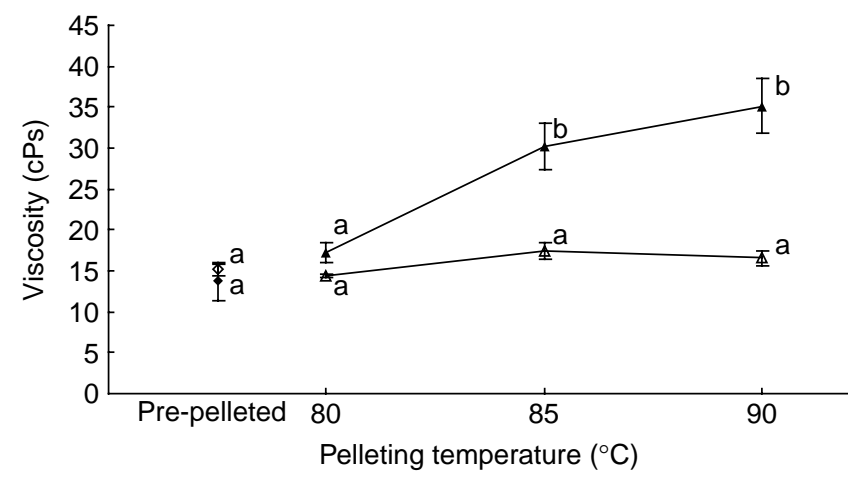

Fig. 1. Viscosity of diets (cPs) in starter diets after an in vitro digestion. $(-\boldsymbol{\Lambda}-)$, Pelleted feed; $\left(-\Delta_{-}\right)$, pelleted feed + xylanase; $(\bullet)$, pre-pelleted feed; $(\diamond)$, pre-pelleted feed + xylanase. Values are means, with their standard errors represented by vertical bars. ${ }^{a, b}$ Mean values with unlike letters were significantly different $(P<0.05)$.

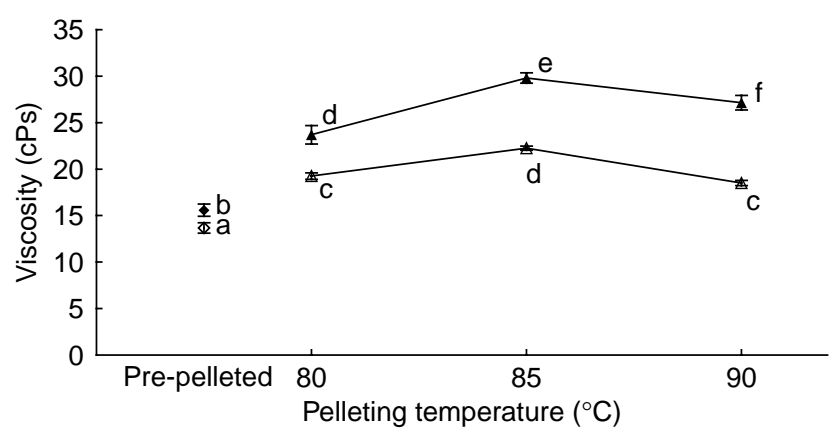

Fig. 2. Viscosity of diets (cPs) in finisher diets after an in vitro digestion. $(-\boldsymbol{\Delta}-)$, Pelleted feed; $(-\Delta-)$, pelleted feed + xylanase; $(\bullet)$, pre-pelleted feed; $(\diamond)$, pre-pelleted feed + xylanase. Values are means, with their standard errors represented by vertical bars. $\mathrm{a}, \mathrm{b}, \mathrm{c}, \mathrm{d}, \mathrm{e}, \mathrm{f}$ Mean values with unlike letters were significantly different $(P<0.05)$. 
exogenous xylanase reduced both viscosity and the degree of polymerisation of the arabinoxylan-based carbohydrates. Similar responses have been noted previously, where an optimal conditioning temperature of $85^{\circ} \mathrm{C}$ was noted for wheat-based broiler diets and adverse effects of higher temperatures were apparent (Silversides \& Bedford, 1999). Furthermore, recently presented data by Scott (2005) showed similar effects on Canadian wheats, where pelleting increased digesta viscosity by approximately $17 \%$, but was significantly reduced with enzyme addition. In addition to changes in diet characteristics associated with thermal treatment, the stability of the enzyme products to heat must be considered. As enzymes are proteinaceous, they are denatured to a varying degree (depending on their tertiary and quaternary conformation) when they are exposed to feed processing conditions that rely on the application of heat to the diet matrix (conditioning and pelleting). Enzymes that are rendered more thermostable, either by directed evolution processes or via coating technology, may have an advantage over less thermostable enzymes, as recovery post-processing is often higher. However, it should be noted that the optimum temperature for enzymes that are thermostable up to $85-90^{\circ} \mathrm{C}$ is often considerably higher than the core temperature in poultry (about $40^{\circ} \mathrm{C}$ ) and so evolved enzymes that exhibit a high degree of intrinsic thermostability may have compromised activity at lower temperatures. These data suggest that, in order to achieve a more consistent response to exogenous xylanase, conditioning temperature should be considered as an important factor.

There have been a number of recent publications advocating the use of whole grain in poultry feeding to improve performance, gut health and to reduce incidence of disease (Svihus et al. 2004; Bjerrum et al. 2005). Bjerrum et al. (2005) presented data that demonstrated that feeding whole wheat to broilers significantly reduced the numbers of Clostridium perfringens in the distal GI tract and concluded that the gizzard is an important barrier organ to prevent undesirable bacteria from successfully colonising the ileum. Apajalahti et al. $(1998,2001)$ have presented similar results, showing desirable changes in the microbial flora associated with the inclusion of whole grain in the diet of broilers (Fig. 3). The interaction between xylanase and whole-grain feeding has not received much attention but publications that do deal with this issue have concluded that the effect of xylanase is largely independent of the presence of whole grain in the diet (Jones \& Taylor, 2001; Engberg et al. 2004; Wu et al. 2004).

\section{Enzymes for maize}

The use of exogenous enzymes in diets that are based on maize is receiving considerable attention in recent literature. This may be because of the size of the global maize feed market, the realisation that maize is a variable feed ingredient and the relatively low degree of penetration of enzyme products into this feed segment, which is an impetus for commercially funded research programmes. A recent review (Cowieson, 2005) summarised the effects of enzyme supplementation of maize-based diets and suggested some modes of action for various enzymes and so will not be repeated in the present review. An earlier review (Summers, 2001) is also comprehensive in summarising the factors in maize that are important in determining its nutritional value for poultry and the effect of exogenous enzymes. The reader is referred to these publications for more detailed information on this subject.

\section{Enzymes for vegetable-protein meals}

Research in the area of enzyme supplementation of proteinaceous feed ingredients for poultry diets is something of a minefield, as knowledge of the substrates is limiting in the extreme. For example, the carbohydrate composition of soyabean meal, oilseed meals, lupin-seed meals and field beans are relatively complex compared with cereals where the carbohydrates are predominantly starchbased (Bach Knudsen, 1997; Choct, 1997; Leske \& Coon, 1999; Graham et al. 2002). Furthermore, the carbohydrates

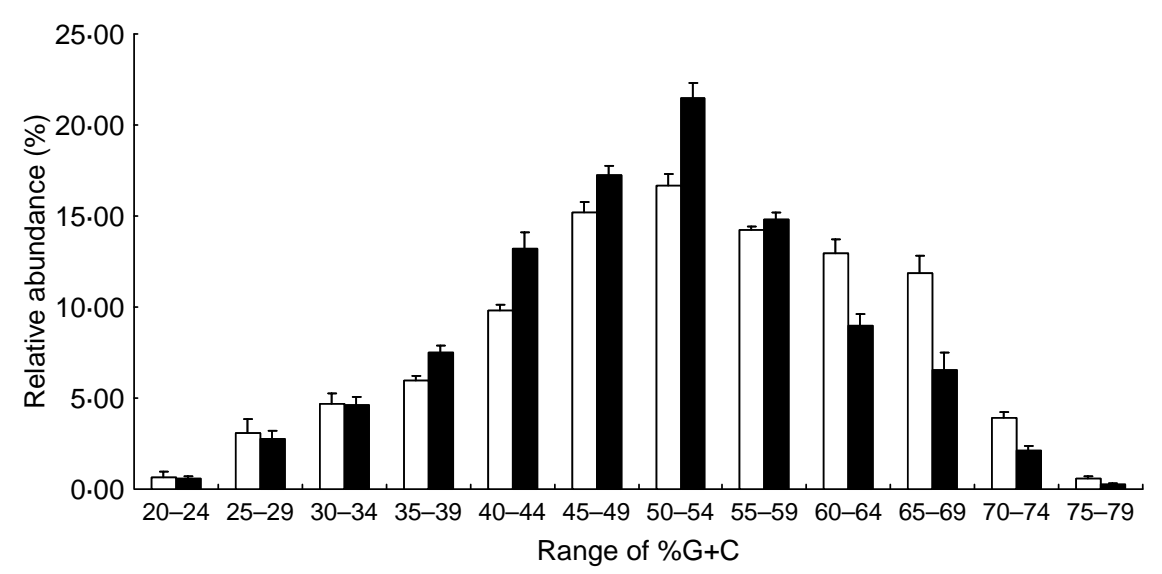

Fig. 3. Effect of whole-wheat amendment on the caecal microbial community of broiler chickens. Caecal microflora was analysed by percentage guanine plus cytosine $(\mathrm{G}+\mathrm{C})$ profiling in three replicate birds from two farms that fed only standard commercial feed $(\square)$ and from two farms that amended this commercial feed with whole wheat $(\boldsymbol{\square})$. Values are means of the abundance of bacteria characterised by \% $\mathrm{G}+\mathrm{C}$, with their standard errors represented by vertical bars. The $\mathrm{G}+\mathrm{C}$ profiling technique and the statistical method are described elsewhere in detail (Apajalahti et al. 1998, 2001). 
themselves in vegetable-protein meals can be anti-nutritive in nature (Cowieson \& Acamovic, 2003). Nevertheless, there have been a large number of studies reported in this area with a wide range of responses to an equally wide range of enzyme candidates (Table 2). A recent paper by Vahjen et al. (2005) showed that the most effective enzymes for soyabean meal were 1,4- $\beta$-arabinogalactanases, but reported that there were some synergies on the release of sugars when this enzyme was combined with a galactomannanase. However, these synergistic in vitro effects were inconsistent in improving performance of broilers in vivo. Indeed, a combination of galactanase and mannanase actually resulted in a reduction in body-weight gain of $22 \%$ compared with birds that were fed on the control ration. The authors concluded that the disappointing effects of enzyme on bird performance may be due to the release of oligomers that increase intestinal osmotic pressure. Similar results have been reported for the use of a combination of polygalacturonase and pectin methyl esterase in an in vitro digestion of lupin-seed meal (Ali et al. 2005). In this study, the combination of pectinases resulted in the greatest degree of hydrolysis of the lupin polysaccharides. However, the authors concluded that although a combination of pectinases can be effective in hydrolysing polysaccharides from lupins, before these enzymes should be tested in vivo, the correct doses should be determined as overdosing pectin methyl esterase may have deleterious effects on bird performance.

Douglas et al. (2000) reported on the effects of enzyme addition (xylanase, amylase and protease) on the performance of broilers fed on diets containing twelve different soyabean-meal samples. In this study they found that the effect of enzyme was dependent on the soyabean-meal batch, which may be due to the inherent digestible energy content of the meal. However, as the authors did not report trypsin inhibitor activity or lectin concentration in each meal, some of the variation in enzyme response may be explained by variance in the content of trypsin inhibitor activity, lectins or the degree of damage to amino acids during processing. Clarke \& Wiseman (2005) recently published data that showed the concentration of trypsin inhibitor in soyabean meal is extremely important in determining the nutritional value of the meal. It may be that the protease component in the enzyme cocktail in the study reported by Douglas et al. (2000) may reduce the adverse effects of trypsin inhibitors in soyabean meal, improving digestible energy and reducing endogenous loss. This hypothesis is supported by data published by Huo et al. (1993) showing that exogenous protease could successfully denature proteinaceous anti-nutrients in vitro in soyabean meal, potentially improving its nutritional value for poultry (Fig. 4). Ghazi et al. (2002) also found that protease was successful in improving the nutritional value of soyabean meal for poultry, concluding that it may be the hydrolysis of antigenic proteins in the meal or improvement in the digestibility of heat-damaged proteins that was responsible for the performance enhancement. This suggests that protease may be one candidate enzyme that is capable of improving the nutritional value of soyabean meal (and possibly other protein meals) by targeting proteinaceous anti-nutrients, antigenic proteins and proteins that have become damaged during processing. Kocher et al. (2002)

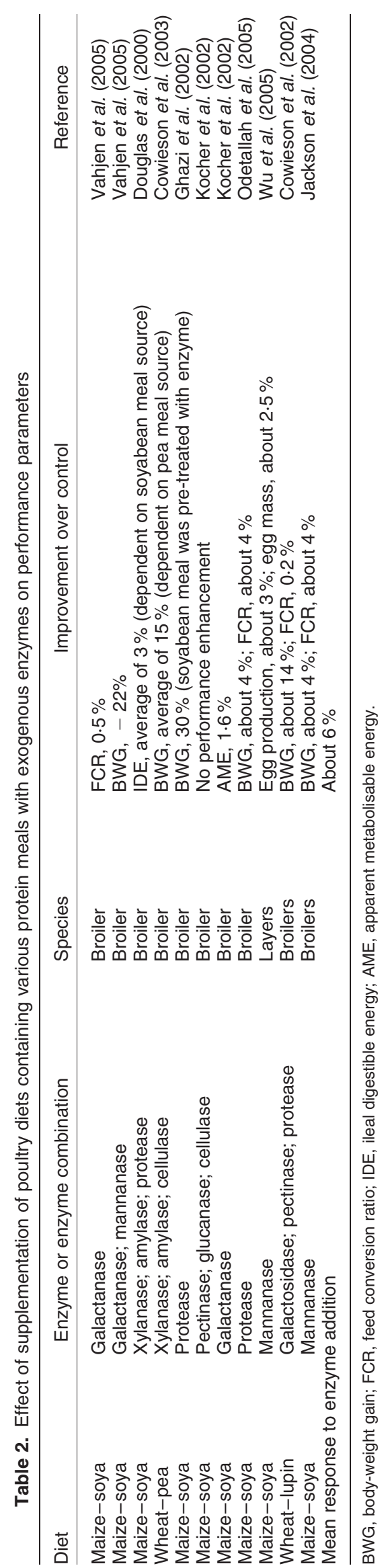




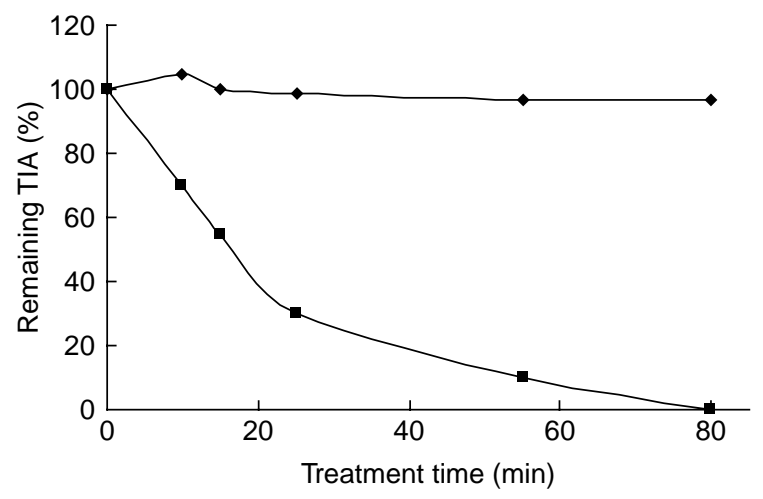

Fig. 4. Loss of trypsin inhibitor activity (TIA) of purified trypsin inhibitors after protease treatment of soyabean-meal slurry. $(\bullet-)$, Control; $(--)$, protease treatment (adapted from Huo et al. 1993).

demonstrated that a $\beta$-galactanase was effective in improving the metabolisable energy content of a diet based on maize and soyabean meal (by $1.6 \% ; P<0.05$ ). The authors concluded that it was the beneficial effects of the enzyme on carbohydrate digestibility that improved the apparent metabolisable energy of the meal. It should be noted, however, that no significance performance (weight gain or FCR) was detected.

There may also be value in enzyme supplementation of diets containing other protein meals. For example, work by Cowieson et al. (2003) demonstrated that the nutritional value of diets containing pea meals could be improved by the addition of an enzyme cocktail containing xylanase, amylase and cellulase, with part of the beneficial effects being conferred via a reduction in the secretion of endogenous mucins. One area that has received relatively little attention to date but which is likely to receive considerably more attention in coming years is the use of distillers dried grains with solubles (DDGS) in the feeding of single-stomached animals and the improvement in the energy value of DDGS with appropriate exogenous enzymes. The nutrient profile of DDGS is relatively good, although there is a high concentration of fibrous material that may limit the inclusion concentration in poultry diets (Table 3; Spiehs et al. 2002; Belyea et al. 2004; Lumpkins et al. 2004). The P concentration in DDGS is about $0.9 \%$ (Spiehs et al. 2002) and has a high bioavailability for poultry (54-100\%; Martinez Amezuca et al. 2004; Lumpkins \& Batal, 2005) compared with other feed ingredients. The high bioavailability of $\mathrm{P}$ suggests that phytase may not be required for DDGS. However, the substantial variability in $\mathrm{P}$ availability in DDGS would be unacceptable to nutritionists and so phytase may be a useful tool to reduce this variance. Due to the high concentration of fibre in DDGS and the variability in nutritional value (Cromwell et al. 1993) there is potential to improve the nutritional value with the use of NSP-degrading enzymes, particularly those with a high affinity for insoluble fibre. Furthermore, the amino acids in DDGS may have a low bioavailability due to damage during drying, which may be particularly acute for lysine (Goodson \& Fontaine, 2004; Lumpkins \& Batal, 2005). Thus, the nutritional value of DDGS may also be improved via the addition of exogenous proteases to the diet or enzymes that

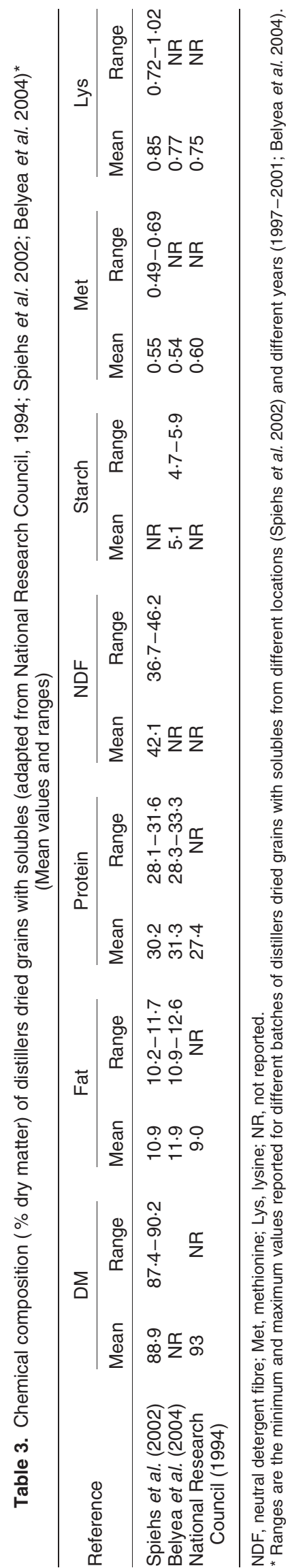


can hydrolyse glucosamine-type compounds. To the authors' knowledge there have been no peer-reviewed publications on the subject of enzyme supplementation of diets containing DDGS for poultry; this is an area that warrants further attention.

\section{Phytase}

Phytase is somewhat unique as an enzyme for animal feed in that it is equally applicable to diets that are based on wheat or barley as for those that are based on maize, and so the potential market for phytases is considerable. Thus, there has been a great deal of research into the efficacy and mode of action of various phytases for the diets of singlestomached animals. It can be concluded that phytase is effective in improving the retention of dietary $\mathrm{P}$ (Simons et al. 1990) and may also improve the retention of dietary amino acids and energy (Selle et al. 2000). One area of recent research into the mode of action of phytase has been related to the effect of phytate and phytase on endogenous secretions and whether some of the beneficial effects of phytase may be attributed to desirable changes in endogenous secretions and mucin production. Recent work by Cowieson et al. (2004) revealed that, in the absence of feed, phytate (fed as an aqueous solution of inositol hexaphosphate) could stimulate an increase in the secretion of endogenous minerals, amino acids and mucin carbohydrates (Fig. 5) from 6-week-old broiler chickens and that phytase could partially ameliorate these adverse effects. These results are supported by Onyango et al. (2004), who demonstrated that the secretion of endogenous mucins was increased by the presence of phytic acid in the intestines of ducks and broilers. It may be that part of the beneficial effects that phytase is capable of exerting in animal diets is by reducing the anti-nutritive effects of phytate, as well as by liberating nutrients from the feed. When the effect of phytase on amino acid digestibility coefficients is considered, the effects are intermittent and dependent on the amino acid (Selle et al. 2000; Adeola \& Sands, 2003; Cowieson et al. 2006a), with improvements in digestibility of threonine, cysteine, arginine and serine with phytase being proportionately greater than, for example, methionine (Biehl \& Baker, 1997; Kornegay et al. 1999; Namkung \& Leeson, 1999; Zhang et al. 1999). It is of significance that the amino acids for which digestibility coefficients are most obviously improved by phytase are those amino acids that

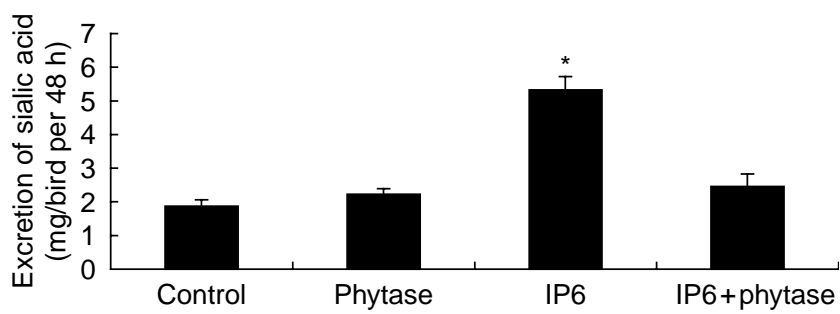

Fig. 5. Effect of phytase and phytic acid (inositol hexaphosphate; IP6) on the excretion of sialic acid from 6-week-old broiler chickens. Values are means, with their standard errors represented by vertical bars. * Mean value was significantly different from that of the control chickens $(P<0.05)$ (adapted from Cowieson et al. 2004). are found in the highest concentrations in endogenous enzymes and mucins (Forstner \& Forstner, 1994).

Watson et al. (2005) recently reported data showing that phytase addition to nutritionally adequate rations could stimulate a further increase in performance. Cowieson et al. $(2006 b, c)$ have also noted such effects with a combination of carbohydrases and phytase in nutritionally adequate diets. This suggests that either the $\mathrm{P}$ requirements of broilers are substantially greater than expected or that phytase may improve the net value of nutrients, improving performance by reducing maintenance requirements.

Further interesting research in this area relates to proteolytic stability of phytase. Onyango et al. (2005) recently published data showing that different phytases (from Peniophora and Escherichia) had different resistances to hydrolysis in the GI tract. This is important, as the primary site of phytate hydrolysis in the GI tract is in the gastric phase (when phytate is most soluble) and so loss of activity would have a significant effect on the bioefficacy of the enzyme. The issue of GI tract stability of enzyme products is of course of relevance to other enzyme systems and also feed additives, such as essential oils, that are claimed to be active in the distal GI tract but must first survive the proximal gut (be it proteolysis, or emulsification and digestion by endogenous lipases).

Clearly, because exogenous phytase has such a dramatic effect on both the retention of exogenous nutrients and endogenous secretions, it is vital that the diet to which phytase is added is designed strategically to allow for these changes in gut ecology and nutrient digestibility. Anecdotal evidence suggests that water intake and excretion increases when phytase is used, which may be related to changes in osmotic stress in the GI tract associated with liberated ions or changes in $\mathrm{Na}$ and $\mathrm{K}$ secretion (Cowieson et al. 2004). Future research for phytase should focus on elucidating the effects on endogenous secretions, protein turnover and the effects of acid-base balance and osmotic potential on the efficacy of phytase and bird performance.

\section{Enzyme combinations}

Logic would suggest that if the use of one enzyme can improve weight gain and FCR of chickens compared with birds that have been fed on a diet containing no enzyme, that the use of two or more enzymes might improve the scale and consistency of the response. The reality is somewhat different; antagonistic (Naveed et al. 1999; Saleh et al. 2004), sub-additive (Zyla et al. 2000; Wu et al. 2004; Leslie et al. 2005; Kim et al. 2005), additive (Zyla et al. 1996; Mulyantini et al. 2005; Juanpere et al. 2005) and synergistic (Ravindran et al. 1999; Cowieson \& Adeola, 2005) effects of enzyme combinations have been reported. One of the reasons for this variety of responses is that the overlap in modes of action of enzymes is not fully understood. For example, phytase can improve the retention of dietary $\mathrm{P}$, amino acids and energy (Selle et al. 2000), but then so can other enzymes such as xylanase (Juanpere et al. 2005; Kim et al. 2005). So, in a diet to which both xylanase and phytase are added, what additivity in response can be expected, and will this be different in diets that are based on maize 
compared with those based on wheat? Recent work by Juanpere et al. (2005) suggests that, as phytate is more closely associated with fibre in wheat than in maize, that the effects of xylanase on $\mathrm{P}$ retention and synergy (or at least additivity) with phytase will be more apparent in wheatbased diets. Data presented by Kim et al. (2005) tend to support this, as they found that xylanase was capable of improving the retention of dietary P. Work by Cowieson \& Adeola (2005) in maize-based diets demonstrated that a carbohydrase and protease cocktail could be successfully combined with phytase to additively enhance nutrient retention in a nutritionally marginal diet. In this trial it was noted that phytase improved the retention of $\mathrm{P}$ and $\mathrm{Ca}$ and the carbohydrase-protease cocktail was effective in improving the retention of energy, DM and $\mathrm{N}$, and when the two enzyme systems were combined there was an additive effect. It seems therefore that in wheat-based diets, xylanase may have a synergistic relationship with phytase due to the tertiary phytate-fibre-mineral complexes but in maize the effects are likely to be additive or sub-additive. Regardless, the use of strategic combinations of enzymes can be extremely effective in improving the nutritional value of diets based on wheat and maize and allows the formulation of very-low-cost diets, thus improving profitability of poultry enterprise.

\section{Enzymes and endogenous secretions}

During the process of digestion there is a net movement of nutrients from the gut lumen into the body. However, there is a simultaneous movement of compounds from various gut-associated tissues into the lumen. These compounds consist mainly of mucins, endogenous enzymes, bile, electrolytes, bicarbonates, sloughed cells and other nitrogenous compounds such as uric acid (Fuller \& Reeds, 1998). Although these endogenous secretions are necessary for efficient digestion, they represent a nutritional cost to the animal, especially in instances where hyper-production takes place, for example when trypsin inhibitors are present in the feed (Clarke \& Wiseman, 2005). However, this nutritional cost is more significant in terms of energy balance than for amino acid requirements, as approximately $90 \%$ of secreted $\mathrm{N}$ is retained by the animal (Krawielitzki et al. 1990, 1994). Thus, it may be concluded that the true 'cost' of endogenous secretions is likely to be more significant for the net energy of a diet than for the effect on amino acid requirements.

Diets and dietary ingredients that are capable of stimulating an increase in endogenous secretions are extremely nutritionally expensive for animals. For example, phytate (Cowieson et al. 2004), tannins (Mansoori \& Acamovic, 1998) and NSP (Larsen et al. 1993; Angkanaporn et al. 1994; Cowieson \& Acamovic, 2003) have all been shown to increase endogenous secretions and reduce the performance of broilers. This evidence leads to the obvious conclusion that exogenous enzymes that hydrolyse these endogenous loss-stimulating anti-nutrients may have (at least part of) their effects explained by a reduction in the secretion of these endogenous compounds. Future research in this area should focus on the effects of exogenous enzymes on nutrient requirements, as this is a largely unexplored area.

\section{Enzymes, immune competence and the microbial flora}

The concentration of micro-organisms in the ileum and caecum of the chicken is substantial and can reach numbers of $10^{9}$ and $10^{11}$ per $\mathrm{g}$ digesta respectively (Apajalahti \& Bedford, 1998). These numbers are extraordinarily high and such a concentration of metabolically active organisms can have a significant effect on the hosts' ability to combat disease and to metabolise nutrients. The bacterial community is very much dependent upon the diet as a source of substrates for metabolism (Wagner \& Thomas, 1977; Savory, 1992). Thus, changes in diet composition or nutrient density can have dramatic effects on the intestinal microfloral populations (Gibson et al. 1996; Hillman, 1999; Reid \& Hillman, 1999; Hopwood et al. 2002), which in turn can influence the ability of the animal to digest and absorb dietary nutrients. So, exogenous enzymes can alter microbial populations indirectly within the GI tract through their action on the substrates that bacteria use as a carbon source (Choct et al. 1999; Bedford, 2000b; Cowieson et al. 2000). As both the transient and resident bacteria in the intestine rely on nutrients that are ingested by the bird for their metabolism and growth (Savory, 1992; Lan et al. 2005), the type of ingredients included in a diet can have a substantial effect on the microbial populations present in the GI tract (Wagner \& Thomas, 1977). Other factors such as GI tract $\mathrm{pH}$, the rate of feed passage, feed particle size, gizzard grinding action, presence of exogenous and endogenous enzymes, high $\mathrm{O}_{2}$ tension, and endogenous antimicrobal compounds such as bile salts help limit microbial proliferation in the small intestine (Bedford, 2000b).

Chickens raised in a germ-free environment and fed on a nutritionally adequate diet grow faster than their conventional counterparts (Muramatsu et al. 1994). However, the presence of a microbial flora in the GI tract of poultry is commercially unavoidable as rearing chickens in a germfree environment is not cost-effective and, in most cases, is unlikely to be logistically feasible. Interestingly, although the growth of germ-free chickens is often faster than that of conventional birds, the ability of the animal to extract energy from a diet, particularly a high-fibre diet, is compromised in the germ-free state (Muramatsu et al. 1991). This is presumably due to the ability of the microbes in the distal GI tract to ferment nutrients that the host is unable to digest, producing waste products that have some energy value for the animal (for example, SCFA). The net result is that chickens that are fed on diets that are relatively low in fibre (for example, those based on maize) are unlikely to benefit as much from the presence of a stable gut flora than those fed on diets that contain a higher concentration of indigestible carbohydrates (for example, those based on wheat or barley). Thus, it is possible for a bird to live synergistically with its microflora, gaining extra energy from the by-products of fibre fermentation in the caecum and colon. This relationship can work well as long as the microflora do not increase in numbers dramatically such that they proliferate in the small intestine or that the dominant species are pathogenic or putrefactive in nature. So, it is not 
only the environmental conditions within the poultry house and management practices that will determine whether or not the birds suffer from a clinical or sub-clinical disease challenge, but the type and composition of diet that is ingested.

When digestion and absorption are optimal, there is a limited amount of easily fermentable substrate (for example, starch or protein) available for rapid digestion by the microflora in the distal GI tract. Conversely, reduced nutrient digestibility by the bird typically occurs when feeding less digestible feed ingredients (Vahjen et al. 1998) or in a situation of high endogenous losses caused by antinutritional compounds in the diet (Cowieson \& Acamovic, 2003; Cowieson et al. 2003, 2004), or, for example, in the presence of gut lesions caused by coccidiosis or other enteric disease challenges. In these instances both unabsorbed nutrients and endogenous secretions or sloughed cells provide easily fermentable substrate for microbes and lead to their proliferation in different parts of the GI tract. Furthermore, there is a delicate balance between the host's ability to combat disease challenge, the diet and the microbial flora in the GI tract.

A well-functioning intestinal tract has to allow transport of nutrients between the gut lumen and the systemic circulation but also prevent the entry of pathogenic agents. A wide range of defence mechanisms functions in the intestine, and may be generally classified as being either non-immunological or immunological. Examples of non-immulogical defence mechanisms are acidity, biliary secretions and proteolytic enzymes that can degrade bacterial cell walls. The adherence of microbes to the epithelium in the upper small intestine can be discouraged by the mechanical action of peristalsis. In addition, mucus, secreted by goblet cells, protects the surface of intestinal epithelium and at the same time provides a viscous matrix that can trap foreign antigens (Forstner \& Forstner, 1994; King, 1998). Fernandez et al. (2000) reported that supplementing broiler feeds with exogenous xylanase affects mucin synthesis. The effect of enzymes on mucin synthesis is not clear but it is possible that xylanase enhances mucin output from the goblet cells by lowering the viscosity of the intestinal content. Furthermore the data suggested that xylanse modifies the $\mathrm{N}$-acetylglucosamine residues of goblet cell mucins along the proximal and distal parts of the chick intestinal tract. The carbohydrate characteristics of intestinal mucins have been reported to prevent attachment by Salmonella typhimurium and Yesinia enterocolitica (Ensgraber et al. 1992). The addition of an enzyme cocktail containing xylanase, amylase and cellulase into a diet containg pea meal had a beneficial effect on a reduction in the secretion of endogenous mucins (Cowieson et al. 2003). It is possible that the action of enzymes to contribute to the presence of a 'normal' gut microflora (one that does not cause clinical or subclinical disease, does not proliferate uncontrollably and provides energy to the host through production of metabolic by-products) enhances host immunity by stimulating the immunological defence mechanisms at the mucosal and systemic level, perhaps by reducing the concentration of saprogenic compounds. Kettunen \&
Rautonen (2005) reported that the use of exogenous enzymes enhances nutrient uptake for the intestinal immune cells contributing to the immunity improvement. The researchers saw an increase in the concentration of IgA in the digesta when supplementing broiler diets with a mixture of xylanase, amylase and protease. The same authors (Kettunen et al. 2005) recently reported that a combination of the enzyme and betaine aided in the immune maturation by increasing CD4 + cells in the ileal tissue and increasing the levels of $\operatorname{IgA}$ in the digesta. Feng et al. (2004) similarly reported increases in immunity-related responses such as natural killer cell activity and serum antibody titres when supplementing diets with exogenous enzymes. The extent to which the immunological defence mechanisms can be manipulated through the exogenous enzyme use depends on an understanding of the cellular and molecular mechanisms underlying the delicate balance between the normal microbiota, mucosal immune components and the effect of different types of enzymes on these processes.

\section{Predictabilty \\ Ingredient quality}

The effect of exogenous enzymes is inexorably linked to their substrates and the subsequent impact on the inherent nutritional value of the feed to which they are added. Thus, knowledge of ingredient quality is vital if enzymes are to be used to their full potential for a consistent and measurable return on investment. Ingredient quality, although a frequently used term, is not actually at all easy to define. In essence, the nutritional quality of a feed ingredient is a function of the concentration and digestibility of the nutrients within, the dilution of those with compounds of no nutritional value (such as cellulose) and the exacerbation by those of a negative nutritive value (such as trypsin inhibitors). When enzymes are added to this nutritional matrix they may be considered to either enhance the digestibility of nutrients or diluents or to reduce the inimical effects of anti-nutrients. It is logical to assume that as enzymes have been shown to reduce variability in, for example, the energy value of an ingredient, that the improvement in energy value will be greater for lowmetabolisable energy ingredients than for ingredients with an inherently higher metabolisable energy content. Indeed, this has been demonstrated in both wheat and soyabean meal (Douglas et al. 2000; Scott, 2005). Douglas et al. (2000) assessed the effect of exogenous enzyme addition to maize-soya-based diets using twelve different batches of soyabean meal. They found that the effect of enzyme was independent of some measured variables such as protein solubility or the protein or gross energy content of the meal but was largely dependent on the base digestible energy content. Similarly, Scott (2005) reported that wheat samples with a high inherent FCR respond well to added enzymes. As knowledge of ingredient quality improves and substrates become more fully characterised it may become easier to develop the next generation of in-feed enzymes.

There are a number of methods that are available to assess the nutritional value of a feed ingredient, including 
performance studies, metabolism studies and in vitro laboratory tests. However, it is not feasible, or indeed ethical, to use large numbers of animals to assess the nutritional value of all feed ingredients before formulation of poultry rations. Thus, it is desirable to have statistical models that are capable of assessing the nutritional value of a given batch of cereal or legume and the response to exogenous enzymes using in vitro tests. This can be achieved by the use of holo-analysis of performance and metabolism data correlated with in vitro parameters (Rosen, $2002 a, b)$.

\section{Animal modelling}

The use of animal models to predict the nutritional value of a feedstuff or the response to a feed additive is not a new concept but has become increasingly sophisticated in recent years, especially with the introduction of neural networks and fuzzy logic to animal growth modelling. Extremely large databases have been generated using published data to yield best-fit algebraic models of responses to various feed additives from $\mathrm{Cu}$ to antimicrobial growth promotants and exogenous enzymes (Rosen, 2001). These models can be extremely useful to the feed industry as they can highlight important variables involved in the response to feed additives that would not be apparent when reviewing the results of only one or two trials. However, models that are based only on published data are inevitably biased towards positive results, as flat or negative responses to feed additives are rarely made public. Furthermore, the variation inherent in models that are based on published data precludes the use of smaller databases to achieve the desired results. Indeed, Rosen $(2002 a, b)$ suggests that a minimum of about 100 tests is required to achieve a working model, a number that must be related directly to the variation within the database. For databases that are developed under more controlled conditions, with lower inherent variance, the number of tests required may be substantially lower. However, if the variance in inputs is too low, the strength of the database will be compromised, as there will be insufficient data to pick out significant variables based on environment, husbandry, etc. Thus, there may be a balance here between high variation, such that true significant effects are overlooked, and a model that is so controlled that it may be considered to be contrived. It can be concluded that the use of least-squares models based on animal performance data are powerful tools to predict the response of the animal to the feed additive under specified nutritional conditions. It is highly likely that in the future the development of novel feed additives, including new enzymes, will be in conjunction with models that are capable of predicting the scale and consistency of the response. This will be particularly true in situations where combinations of feed additives are used that may or may not be sub-additive, additive or synergistic in their responses. Thus, if new feed enzymes or other additives are developed without complimentary services based on statistical models, recommendations for optimum doses must be considered to be educated guesses at best.

\section{Future developments}

It is difficult to predict what the next leap forward will be in the field of feed enzyme research. However, there are some obvious gaps in knowledge that may lead to discoveries with significant implications. The effect of enzymes on nutrient requirements and the net value of energy and amino acids is a largely unexplored area. For example, does exogenous protease have a sparing effect on endogenous protease production via a hormonally controlled feedback mechanism? If so, then it is possible that supplemental enzymes may reduce the birds' requirements for energy and amino acids. This may hold true for other enzymes such as amylase, maltase, isomaltase and lipase. There is no reason to 'allow' the animal to produce its own enzyme compliment if it cannot do so more cheaply than is true for commercial fermentation processes or if it is overwhelmed by substrate under some specific stressful circumstances or conditions (for example, neonates, intestinal disease, etc). Another area that is largely uninvestigated is the use of enzymes as direct antimicrobials to lyse attachment polysaccharides or bacterial cell walls and the effect of enzymes on the immune competence of the host. The provision of substrates for 'beneficial' bacteria by targeted enzymes and the potential impact on immune status is another fertile area for future research. Finally, the effect of bird age on enzyme dose recommendations has not been well elucidated. It is likely that younger animals will have a different 'requirement' for enzymes than older animals, such that the enzyme(s) of choice and optimum dose will change with age. Although there are many new avenues for exploration in this field there are also considerable challenges facing the feed-enzyme industry. These include increasingly stringent regulatory requirements within and outwith the European Union and uncertain future restrictions on the acceptability of the use of GM organisms to produce enzymes. In addition, as increasingly 'bioactive' and concentrated enzymes are developed, it is critical that producers of these products ensure that, even at low inclusion concentrations, the homogeneity in-feed is maintained at an acceptable level. Despite these challenges, the use of exogenous enzymes to achieve nutritional goals within the poultry industry is likely to continue well into the future.

\section{Conclusions}

Exogenous enzymes are effective in improving the nutritional value of poultry diets and subsequent animal performance. However, the effect on the net value of nutrients, the microbial flora, immune competence and the degree by which substrate quality and variability influence enzyme bioefficacy are not fully elucidated. By equipping decision-makers with both efficacious and cost-effective products and the knowledge they require in order to maximise return on investment, and not simply suggesting an arbitrary dose based on minimum cost per tonne treated, companies that market feed enzymes will have a strategic advantage in what is becoming an increasingly competitive environment. 


\section{References}

Adeola O \& Bedford MR (2005) Exogenous dietary xylanase ameliorates viscosity-induced anti-nutritional effects in wheatbased diets for White Pekin ducks (Anas platyrinchos). British Journal of Nutrition 92, 87-94.

Adeola O \& Sands JS (2003) Does supplemental microbial phytase improve amino acid utilization? A perspective that it does not. Journal of Animal Science 81, 78-85.

Ali A, Williams IH, Martin GB \& Sipas S (2005) Hydrolysis of lupin pectin by pectinases for broilers. Proceedings of the Australian Poultry Science Symposium 17, 219-222.

Angkanaporn K, Choct M, Bryden WL, Annison EF \& Annison G (1994) Effects of wheat pentosans on endogenous amino acid losses in chickens. Journal of the Science of Food and Agriculture 66, 399-404.

Apajalahti JHA \& Bedford MR (1998) Nutrition effects on the microflora in the GI tract. In Proceedings of the 19th Western Nutrition Conference, pp. 60-68. Saskatoon, Saskatchewan, Canada: University of Saskatchewan Extension Press.

Apajalahti JHA, Kettunen A, Bedford MR \& Holben WE (2001) Percent $\mathrm{G}+\mathrm{C}$ profiling accurately reveals diet-related differences in the gastrointestinal microbial community of broiler chickens. Applied Environmental Microbiology 67, 5656-5667.

Apajalahti JHA, Sarkilahti LK, Maki BR, Heikkinen JP, Nurminen PH \& Holben WE (1998) Effective recovery of bacterial DNA and percent-guanine-plus-cytosine-based analysis of community structure in the gastrointestinal tract of broiler chickens. Applied Environmental Microbiology 64, 4084-4088.

Bach Knudsen KE (1997) Carbohydrate and lignin contents of plant materials used in animal feeding. Animal Feed Science and Technology 67, 319-338.

Bedford MR (2000a) Exogenous enzymes in monogastric nutrition - their current value and future benefits. Animal Feed Science and Technology 86, 1-13.

Bedford MR (2000b) Removal of antibiotic growth promoters from poultry diets: implications and strategies to minimize subsequent problems. World's Poultry Science Journal 56, 347-366.

Bedford MR (2002) The role of carbohydrases in feedstuff digestion. In Poultry Feedstuffs: Supply, Composition and Nutritive Value, pp. 319-336 [J McNab and N Boorman, editors]. Wallingford, UK: CAB International.

Bedford MR \& Classen HL (1992) Reduction of intestinal viscosity through manipulation of dietary rye and pentosanase concentration is effected through changes in the carbohydrate composition of the intestinal aqueous phase and results in improved growth rate and food conversion efficiency of broiler chicks. Journal of Nutrition 122, 560-569.

Bedford MR \& Classen HL (1993) An in vitro assay for prediction of broiler intestinal viscosity and growth when fed rye-based diets in the presence of exogenous enzymes. Poultry Science 72, 137-143.

Bedford MR, Classen HL \& Campbell GL (1991) The effect of pelleting, salt and pentosanase on the viscosity of intestinal contents and performance of broilers fed rye. Poultry Science $\mathbf{7 0}$, $1571-1577$

Belyea RL, Rausch KD \& Tumbleson ME (2004) Composition of maize and distillers dried grains with solubles from dry grind ethanol processing. Bioresearch Technology 94, 293-298.

Biehl RR \& Baker DH (1997) Microbial phytase improves amino acid utilization in young chicks fed diets based on soyabean meal but not diets based on peanut meal. Poultry Science 76, 355-360.

Bjerrum L, Pedersen AB \& Engberg RM (2005) The influence of whole wheat feeding on Salmonella infection and gut flora composition in broilers. Avian Disease 49, 9-15.
Bonnin E, Daviet S, Gebruers K, Delcour JA, Goldson A, Juge N \& Saulnier L (2005) Variation in the levels of the different xylanase inhibitors in grain and flour of 20 French wheat cultivars. Journal of Cereal Science 41, 375-379.

Choct M (1997) Feed non-starch polysaccharides: chemical structure and nutritional significance. Feed Milling International, June 1997, pp. 13-26.

Choct M, Hughes RJ \& Bedford MR (1999) Effects of xylanase on individual bird variation, starch digestion throughout the intestine, and ileal and caecal volatile fatty acid production in chickens fed wheat. British Poultry Science 40, 419-422.

Choct M, Kocher A, Waters DL, Pettersson D \& Ross G (2004) A comparison of three xylanases on the nutritive value of two wheats for broiler chickens. British Journal of Nutrition 92, $53-61$.

Clarke E \& Wiseman J (2005) Effects of variability in trypsin inhibitor content of soya bean meals on true and apparent ileal digestibility of amino acids and pancreas size in broiler chickens. Animal Feed Science and Technology 121, 125-138.

Cowieson AJ (2005) Factors that affect the nutritional value of maize for broilers. Animal Feed Science and Technology 119, 293-305.

Cowieson AJ \& Acamovic T (2003) Lupin non-starch polysaccharides and their effects on chickens. In Poisonous Plants and Related Toxins, pp. 304-309 [T Acamovic, CS Stewart and TW Pennycott, editors]. Wallingford, UK: CAB International.

Cowieson AJ, Acamovic T \& Bedford MR (2002) The effects of enzyme supplementation and lupin cultivar on the performance and endogenous losses of broiler chicks. In Proceedings of the 10th International Lupin Conference, Laugarvatn, Iceland, June 2002, pp. 323-328. [E van Santen and GD Hill, editors]. Canterbury, New Zealand: International Lupin Association, Lincoln University.

Cowieson AJ, Acamovic T \& Bedford MR (2003) Supplementation of diets containing pea meal with exogenous enzymes: effects on weight gain, feed conversion, nutrient digestibility and gross morphology of the gastrointestinal tract. British Poultry Science 44, 427-437.

Cowieson AJ, Acamovic T \& Bedford MR (2004) The effect of phytase and phytic acid on endogenous losses from broiler chickens. British Poultry Science 45, 101-108.

Cowieson AJ, Acamovic T \& Bedford MR (2006a) Phytic acid and phytase: implications for protein utilisation by poultry. Poultry Science 85, 878-885.

Cowieson AJ \& Adeola O (2005) Carbohydrases, protease, and phytase have an additive beneficial effect in nutritionally marginal diets for broiler chicks. Poultry Science 84, $1860-1867$

Cowieson AJ, Hruby M \& Faurschou Isaksen M (2005) The effect of conditioning temperature and exogenous xylanase addition on the viscosity of wheat-based diets and the performance of broiler chicks. British Poultry Science 46, 717-724.

Cowieson AJ, Sarkilahti LK, Apajalahti JHA, Acamovic T \& Bedford MR (2000) Caecal microflora in broilers fed diets containing Camelina with and without enzyme supplementation. In Proceedings of the XXI World's Poultry Congress, CD ROM. Montreal, Quebec, Canada: World's Poultry Science Association; Candian Branch.

Cowieson AJ, Singh DN \& Adeola O (2006b) Prediction of ingredient quality and the effect of a combination of xylanase, amylase, protease and phytase on the performance of broiler chicks. I. Growth performance and digestible nutrient intake. British Poultry Science (In the Press).

Cowieson AJ, Singh DN \& Adeola O (2006c) Prediction of ingredient quality and the effect of a combination of xylanase, amylase, protease and phytase on the performance of broiler 
chicks. II. Energy and nutrient utilization. British Poultry Science (In the Press).

Cromwell GL, Herkelman KL \& Stahly TS (1993) Physical, chemical and nutritional characteristics of distillers grains with solubles for chicks and pigs. Journal of Animal Science 71, 679-686.

Douglas MW, Parsons CM \& Bedford MR (2000) Effect of various soybean meal sources and Avizyme on chick growth performance and ileal digestible energy. Journal of Applied Poultry Research 9, 74-80.

Engberg RM, Hedemann MS, Steenfeldt S \& Jensen BB (2004) Influence of whole wheat feeding and xylanase on broiler performance and microbial composition and activity in the digestive tract. Poultry Science 83, 925-938.

Ensgraber M, Genitsariotis R, Storkel S \& Loos M (1992) Purification and characterisation of a Salmonella typhimurium agglutinin from gut mucus secretions. Microbial Pathogenesis 12, 255-266.

Feng G, Yun J, Guang-Hong Z \& Zheng-Kang H (2004) Effects of non-starch polysaccharide enzyme supplements on the growth, immune function and gastrointestinal microflora of chicks. Chinese Journal of Veterinary Science 24, 501-503.

Fernandez F, Sharma R, Hinton M \& Bedford MR (2000) Diet influences the colonization of Camplyobacter jejuni and distribution of mucin carbohydrates in the chick intestinal tract. Cellular and Molecular Life Sciences 57, 1793-1801.

Fontes CMGA, Ponte PIP, Reis TC, Soares MC, Gama LT, Dias FMV \& Ferreira LMA (2004) A family 6 carbohydrate-binding module potentiates the efficacy of a recombinant xylanase used to supplement cereal-based diets for poultry. British Poultry Science 45, 648-656.

Forstner JF \& Forstner GG (1994) Gastrointestinal mucus. In Physiology of the Gastrointestinal Tract, pp. 1255-1283 [LR Johnson, editor]. New York: Raven Press.

Fuller MF \& Reeds PJ (1998) Nitrogen cycling in the gut. Annual Reviews of Nutrition 18, 385-411.

Gebruers K, Brijs K, Courtin CM, Fierens K, Goesaert H, Rabijns A, Raedschelders G, Robben J, Sansen S \& Sørensen JF (2004) Properties of TXAI-type endoxylanase inhibitors. Biochimica et Biophysica Acta 1696, 213-221.

Gebruers K, Courtin CM, Goesaert H, van Campenhout S \& Delcour JA (2002) Endoxylanase inhibition activity in different European wheat cultivars and milling fractions. Journal of Cereal Chemistry 79, 613-616.

Ghazi S, Rooke JA, Galbraith H \& Bedford MR (2002) The potential for the improvement of the nutritive value of soya-bean meal by different proteases in broiler chicks and broiler cockerels. British Poultry Science 43, 70-77.

Gibson GR, Willems A, Reading S \& Collins MD (1996) Fermentation of non-digestible oligosaccharides by human colonic bacteria. Proceedings of the Nutrition Society 55, 899-912.

Goodson J \& Fontaine J (2004) Variability in DDGS from ethanol plants. Feed Management 55, 20-25.

Graham H, Simmins PH \& Sands JS (2003) Reducing environmental pollution using animal feed enzymes. Communications in Agriculture and Applied Biological Science 68, 285-289.

Graham KK, Kerley MS, Firman JD \& Allee GL (2002) The effect of enzyme treatment of soybean meal on oligosaccharide disappearance and chick growth performance. Poultry Science 81, 1014-1019.

Hillman K (1999) Manipulation of the proportions of Lactobacillus spp. to coliform bacteria in the piglet colon using dietary starches. In Proceedings of the British Society of Animal Science. Penicuik, Midlothian, UK: British Society of Animal Science.
Hopwood DE, Pethick DW \& Hampson DJ (2002) Increasing the viscosity of the intestinal contents stimulates proliferation of enterotoxigenic Escherichia coli and Brachyspira pilosicoli in weaner pigs. British Journal of Nutrition 88, 523-532.

Huo GC, Fowler VR, Inborr J \& Bedford MR (1993) The use of enzymes to denature antinutritive factors in soybean. In Proceedings of the 2nd International Workshop on ANFs in Legume Seed, Wageningen, paper 60. Wageningen, The Netherlands: European Association for Animal Production.

Ingelbrecht JA, Verwimp T \& Declour JA (2000) Endoxylanases in durum wheat semolina processing: solubilization of arabinoxylans, action of endogenous inhibitors, and effects on rheological properties. Journal of Agriculture and Food Chemistry 48, 2017-2022.

Jackson ME, Geronian K, Knox A, McNab J \& McCartney E (2004) A dose-response study with the feed enzyme $\beta$ mannanase in broilers provided with maize-soybean meal based diets in the absence of antibiotic growth promoters. Poultry Science 83, 1992-1996.

Jones GPD \& Taylor RD (2001) Whole grain in pelleted diets for broiler chicks. British Poultry Science 42, 477-483.

Juanpere J, Perez-Vendrell AM, Angulo E \& Brufau J (2005) Assessment of potential interactions between phytase and glycosidase enzyme supplementation on nutrient digestibility in broilers. Poultry Science 84, 571-580.

Kettunen H \& Rautonen N (2005) With betaine and exogenous enzymes towards improved intestinal health and immunity, and better performance of broiler chicks. Proceedings of the Poultry Science Association. Poultry Science 84, Suppl. 1, 47 Abstr.

Kettunen H, Simmins H \& Rautonen N (2005) Improved intestinal health and immunity in broiler chicks when fed a combination of Betafin and Avizyme 1500. In Proceedings of Antimicrobial Growth Promoters: Worldwide Ban on the Horizon? Noordwijk aan Zee, the Netherlands, 2005, p. 113 [D Barug, J de Jong, AK Kics and MWA Verstegan, editors].

Kim JC, Simmins PH, Mullan BP \& Pluske JR (2005) The effect of wheat phosphorus content and supplemental enzymes on digestibility and growth performance of weaner pigs. Animal Feed Science and Technology 118, 139-152.

King TP (1998) The carbohydrate biology of intestinal surfaces: interactions with dietary and microbial constituents. In Proceedings of the 19th Western Nutrition Conference, pp. 69-88. Saskatoon, Saskatchewan, Canada: University of Saskatchewan Extension Press.

Kocher A, Choct M, Porter MD \& Broz J (2002) Effects of feed enzymes on nutritive value of soybean meal fed to broilers. British Poultry Science 43, 54-63.

Kornegay ET, Denbow DM \& Zhang Z (1999) Influence of microbial phytase supplementation of a low protein/amino acid diet on performance, ileal digestibility of protein and amino acids, and carcass measurements of finishing broilers. In Phytase in Animal Nutrition and Waste Management, pp. 557-572 [MB Coelho and ET Kornegay, editors]. Mount Olive, NJ: BASF Corporation.

Krawielitzki K, Kreienbring F, Zebrowska T, Schadereit R \& Kowalczyk J (1994) Estimation of $\mathrm{N}$ absorption, secretion and reabsorption in different intestinal sections of growing pigs using the ${ }^{15} \mathrm{~N}$ isotope dilution method. In Proceedings of the 6th International Digestive Physiology of Pigs, Dummerstorf, Germany, pp. 79-82 [WB Souffrant and H Hagemeister, editors]. Wageningen, The Netherlands: European Association for Animal Production.

Krawielitzki K, Zebrowska T, Schaderiet R, Kowalczyk J \& Henning U (1990) Determining of nitrogen absorption and nitrogen secretion in different sections of the pigs intestine by digesta exchange between ${ }^{15} \mathrm{~N}$ labeled and unlabeled animals. Archives of Animal Nutrition 40, 25-37. 
Lan Y, Verstegen MWA, Tamminga S \& Williams BA (2005) The role of the commensal gut microbial community in broiler chickens. World's Poultry Science Journal 61, 95-104.

Larsen FM, Moughan PJ \& Wilson MN (1993) Dietary fibre viscosity and endogenous protein excretion at the terminal ileum of growing rats. Journal of Nutrition 123, 1898-1904.

Lazaro R, Garcia M, Aranibar MJ \& Mateos GG (2003) Effect of enzyme addition to wheat-, barley- and rye-based diets on nutrient digestibility and performance of laying hens. British Poultry Science 44, 256-265.

Leske KL \& Coon CN (1999) Nutrient content and protein and energy digestibilities of ethanol-extracted, low $\alpha$-galactoside soybean meal as compared to intact soybean meal. Poultry Science 78, 1177-1183.

Leslie MA, Moran ET \& Bedford MR (2005) The effects of phytase and glycanase supplementation to corn soy diets on AME. Poultry Science 84, Supp.1, 106.

Lumpkins BS \& Batal AB (2005) The bioavailability of lysine and phosphorus in distillers dried grains with solubles. Poultry Science 84, 581-586.

Lumpkins BS, Batal AB \& Dale NM (2004) Evaluation of distillers grains with solubles as a feed ingredient for broilers. Poultry Science 83, 1891-1896.

McLauchlan WR, Garcia-Conesa MT, Williamson G, Roza M, Ravenstein P \& Maat J (1999) A novel class of protein from wheat which inhibits xylanases. Biochemical Journal 338, 441-446.

Mansoori B \& Acamovic T (1998) The influence of tannic acid on the amino acid digestibility in broilers. In Toxic Plants and other Natural Toxicants, pp. 106-110 [T Garland and AC Barr, editors]. Wallingford, UK: CAB International.

Martinez Amezuca M, Parsons CM \& Noll SL (2004) Content and relative bioavailability of phosphorus in distillers dried grains with solubles in chicks. Poultry Science 83, 971-976.

Mathlouthi N, Juin H \& Larbier M (2003a) Effect of xylanase and beta-glucanase supplementation of wheat- or wheat- and barleybased diets on the performance of male turkeys. British Poultry Science 44, 291-298.

Mathlouthi N, Mohamed MA \& Larbier M (2003b) Effect of enzyme preparation containing xylanase and beta-glucanase on performance of laying hens fed wheat/barley- or maize/soybean meal-based diets. British Poultry Science 44, 60-66.

Meng X, Slominski BA, Nyachoti CM, Campbell LD \& Guenter W (2005) Degradation of cell wall polysaccharides by a combination of carbohydrase enzymes and their effect on nutrient utilization and broiler chicken performance. Poultry Science 84, 37-47.

Mulyantini NGA, Choct M, Li X \& Lole UR (2005) The effect of xylanase, phytase and lipase supplementation on the performance of broiler chickens fed a diet with a high level of rice bran. Proceedings of the Australian Poultry Science Symposium 17, 305-307.

Muramatsu T, Kodama H, Morishita T, Furuse M \& Okumura J (1991) Effect of intestinal microflora on digestible energy and fibre digestion in chickens fed a high-fibre diet. American Journal of Veterinary Research 52, 1178-1181.

Muramatsu T, Nakajima S \& Okumura J (1994) Modification of energy metabolism by the presence of the gut microflora in the chicken. British Journal of Nutrition 71, 709-717.

Namkung H \& Leeson S (1999) Effect of phytase enzyme on dietary nitrogen-corrected apparent metabolizable energy and the ileal digestibility of nitrogen and amino acids. Poultry Science 78, 1317-1319.

National Research Council (1994) Nutrient Requirements of Poultry, 9th revised ed. Washington, DC: National Academy Press.
Naveed A, Acamovic T \& Bedford MR (1999) The influence of carbohydrase and protease supplementation on amino acid digestibility of lupin-based diets for broiler chicks. Proceedings of the Australian Poultry Science Symposium 11, 93-96.

Nilsson M, Andersson R, Andersson RE, Autio K \& Åman P (2000) Heterogeneity in water-extractable rye arabinoxylan with a low degree of distribution. Carbohydrate Polymers 41, $397-405$.

Odetallah NH, Wang JJ, Garlich JD \& Shih JCH (2005) Versazyme supplementation of broiler diets improves market growth performance. Poultry Science 84, 858-864.

Onyango EM, Asem EK, Sands JS \& Adeola O (2004) Dietary phytates increase endogenous losses in ducks and chickens. Journal of Animal Science 82, Suppl. 1, 149-150.

Onyango EM, Bedford MR \& Adeola O (2005) Phytase activity along the gastrointestinal tract of the broiler chick: a comparative study of an Eschericia coli-derived and Peniophora lycii phytase. Canadian Journal of Animal Science 85, 61-68.

Ponte PIP, Ferreira LMA, Soares MAC, Gama LT \& Fontes CMGA (2004) Xylanase inhibitors affect the action of exogenous enzymes used to supplement Triticum durum-based diets for broiler chicks. Journal of Applied Poultry Research 13, 660-666.

Ravindran V, Selle PH \& Bryden WL (1999) Effects of phytase supplementation, individually and in combination, with glycanase, on the nutritive value of wheat and barley. Poultry Science 78, 1588-1595.

Reid CA \& Hillman K (1999) The effects of retrogradation and amylose/amylopectin ratio of starches on carbohydrate fermentation and microbial populations in the porcine colon. Animal Science 68, 503-510.

Rosen GD (2001) The nutritive value of phytase in broilers. In Proceedings of the 13th Symposium on Poultry Nutrition, Blankenberge, Belgium, pp. 215-220.

Rosen GD (2002a) Exogenous enzymes as pro-nutrients in broiler diets. In Recent Advances in Animal Nutrition, pp. 89-103 [PC Garnsworthy and J Wiseman, editors]. Nottingham, UK: Nottingham University Press.

Rosen GD (2002b) Microbial phytase in broiler nutrition. In Recent Advances in Animal Nutrition, pp. 105-117 [PC Garnsworthy and $\mathrm{J}$ Wiseman, editors]. Nottingham, UK: Nottingham University Press.

Saleh F, Ohtsuka A, Tanaka T \& Hayashi K (2004) Carbohydrases are digested by proteases present in enzyme preparations during in vitro digestion. Journal of Poultry Science 41, 220-235.

Savory CJ (1992) Enzyme supplementation, degradation and metabolism of three ${ }^{14} \mathrm{C}$-labelled cell-wall substrates in the fowl. British Journal of Nutrition 67, 91-102.

Scott TA (2005) The impact of pelleting and enzyme supplementation on feed value of twenty-five Canadian wheat samples. Proceedings of the Australian Poultry Science Symposium 17, 138-144.

Selle PH, Ravindran V, Caldwell RA \& Bryden WL (2000) Phytate and phytase: consequences for protein utilization. Nutrition Research Reviews 13, 255-278.

Shakouri MD \& Kermanshahi H (2005) Effect of NSP degrading enzyme supplement on the nutrient digestibility of young chickens fed wheat with different viscosities and triticale. Journal of Agricultural and Scientific Technology 5, 105-112.

Sieo CC, Abdullah N, Tan WS \& Ho YW (2005) Influence of $\beta$ glucanase-producing Lactobacillus strains on intestinal characteristics and feed passage rate of broiler chickens. Poultry Science 84, 734-741.

Silversides FG \& Bedford MR (1999) Effect of pelleting temperature on the recovery and efficacy of a xylanase enzyme in wheat-based diets. Poultry Science 78, 1184-1190. 
Simons PC, Versteegh HA, Jongbloed AW, Kemme PA, Slump P, Bos KD, Wolters MG, Beudeker RF \& Verschoor GJ (1990) Improvement in phosphorus availability by microbial phytase in broilers and pigs. British Journal of Nutrition 64, 525-540.

Spiehs MJ, Whitney MH \& Shurson GC (2002) Nutrient database for distiller's dried grains with solubles produced from new ethanol plants in Minnesota and South Dakota. Journal of Animal Science 80, 2639-2645.

Summers JD (2001) Maize: factors affecting its digestibility and variability in its feeding value. In Enzymes in Farm Animal Nutrition, pp. 109-124 [MR Bedford and GG Partridge, editors]. Wallingford, UK: CAB International.

Svihus B, Juvik E, Hetland H \& Krogdahl A (2004) Causes for improvement in nutritive value of broiler chicken diets with whole wheat instead of ground wheat. British Poultry Science 45, 55-60.

Timmler R \& Rodehutscord M (2001) Efficiency of different xylanase preparations in diets for Pekin ducks. Archiv für Tierernährung 55, 315-332.

Vahjen W, Glaser K, Schafer K \& Simon O (1998) Influence of xylanase-supplemented feed on the development of selected bacterial groups in the intestinal tract of broiler chicks. Journal of Agricultural Science 130, 489-500.

Vahjen W, Busch T \& Simon O (2005) Study on the use of soyabean polysaccharide degrading enzymes in broiler nutrition. Animal Feed Science and Technology 120, 259-276.

van der Klis JD, van Voorst A \& van Cruyningen C (1993) Effect of a soluble polysaccharide (carboxy methyl cellulose) on the physico-chemical conditions in the gastrointestinal tract of broilers. British Poultry Science 34, 971-983.

Wagner DD \& Thomas OP (1977) Influence of diets containing rye or pectin on the intestinal flora of chicks. Poultry Science 57, 971-975.

Wang ZR, Qiao SY, Lu WQ \& Li DF (2005) Effects of enzyme supplementation on performance, nutrient digestibility, gastrointestinal morphology, and volatile fatty acid profiles in the hind gut of broilers fed wheat-based diets. Poultry Science 84, 875-881.

Watson BC, Matthews JO, Southern LL \& Shelton JL (2005) The interactive effects of Eimeria acervulina and phytase for broiler chicks. Poultry Science 84, 910-913.

Wu G, Bryant MM, Voitle RA \& Roland DA Sr (2005) Effects of $\beta$-mannanase in maize-soy diets on commercial leghorns in second-cycle hens. Poultry Science 84, 894-897.

Wu YB, Ravindran V, Thomas DG, Birtles MJ \& Hendriks WH (2004) Influence of method of whole wheat inclusion and xylanase supplementation on the performance, apparent metabolisable energy, digestive tract measurements and gut morphology of broilers. British Poultry Science 45, 385-394.

Yasar S \& Forbes JM (1999) Performance and gastro-intestinal response of broiler chickens fed on cereal grain-based foods soaked in water. British Poultry Science 40, 65-76.

Yasar S \& Forbes JM (2000) Enzyme supplementation of dry and wet wheat-based feeds for broiler chickens: performance and gut responses. British Journal of Nutrition 84, 297-307.

Zhang ZB, Kornegay ET \& Denbow DN (1999) Evaluation of phytase and non-starch polysaccharide (NSP) enzymes added alone and in combination on nutrient utilization of individual and mixtures of feedstuffs with adult cecectomized roosters. Poultry Science 78, Suppl. 1, 73 Abstr.

Zyla K, Ledoux DR, Kujawski M \& Veum TL (1996) The efficacy of an enzymic cocktail and a fungal mycelium in dephosphorylating maize-soybean meal-based feeds fed to growing turkeys. Poultry Science 75, 381-387.

Zyla K, Wikiera A, Koreleski J, Swiatkiewicz S, Piironen J \& Ledoux DR (2000) Comparison of the efficacies of a novel aspergillus niger mycelium with separate and combined effectiveness of phytase, acid phosphatase, and pectinase in dephosphorylation of wheat-based feeds fed to growing broilers. Poultry Science 79, 1434-1443. 